\title{
MANAJEMEN PENDIDIKAN DAN PELATIHAN TILAWAH AL-QUR'AN BAGI CALON PESERTA DIDIK MUSABAQOH TILAWATIL QUR`AN
}

\section{AL-QUR`AN READING EDUCATION MANAGEMENT FOR PROSPECTIVE STUDENTS READING RACE AL-QUR'AN}

\author{
A Pertiwi ${ }^{1 a}$ \\ 1 Program Studi Manajemen Pendidikan Islam, Fakultas Keguruan dan Ilmu Pendidikan, \\ Universitas Djuanda Bogor, Jl. Tol Ciawi No. 1 Kotak Pos 35 Ciawi Bogor 16720 \\ a Korespondensi: Afriska Pertiwi, Email: afriska.pertiwi.21@unida.ac.id \\ (Diterima: 08-03-2018; Ditelaah: 08-03-2018; Disetujui: 20-04-2018)
}

\begin{abstract}
The purpose of this study was to determine how the recitation of the Qur'an management education for prospective students boarding school race koran reading the Koran Muhammad Al-Fasyni Thoha Bogor. This research method is using qualitative research with descriptive trying to carry out an assessment to be formulated in the form of reports and descriptions. The type of research by taking a case study in a boarding school Al-Quran muhammad Thoha fasyni city of Bogor. The data collection techniques used were observation, interviews, and documentation. Results of the analysis in this study shows the method patterned, in education management is reading the Quran for prospective learners race reading the Quran, the method is applied to meeting the teacher with the students to practice what the teachers say and demonstrated, in every meeting so as to obtain the pattern of the song reading well. The results of this study can be used by the boarding school related to education management reading the Quran, in an effort to improve the quality of education of reading the Quran. And so it can be evidenced by the increase achievement didikdalam participants race each race recitation of the Qur'an in various places.
\end{abstract}

Keywords: education, learners, management, race reading koran, reading the Koran.

\begin{abstract}
ABSTRAK
Tujuan penelitian ini adalah untuk mengetahui bagaimana manajemen pendidikan dan pelatihan tilawah al-Qur'an bagi calon peserta didik musabaqah tilawatil Qur'an di pondok pesantren al-Qur'an M. Thoha Al-fasyni Bogor. Metode penelitian ini adalah menggunakan penelitian kualitatif dengan berusaha melaksanakan pengkajian deskriptif yang akan dituangkan dalam bentuk laporan dan uraian. Adapun jenis penelitiannya dengan mengambil studi kasus di pondok pesantren al-Qur`an M. Thoha Al-fasyni kota Bogor. Teknik pengumpulan data yang digunakan adalah observasi, wawancara, dan dokumentasi. Hasil analisis pada penelitian ini menunjukkan metode terpola, dalam manajemen pendidikan dan pelatihan tilawah al-Qur`an bagi calon peserta didik musabaqah tilawatil Qur`an, metode ini diterapkan dengan pertemuan guru dan para peserta didik untuk mempraktekan apa yang telah guru sampaikan dan contohkan, dalam setiap kali pertemuan sehingga mampu memperoleh pola lagu tilawah dengan baik. Hasil penelitian ini dapat digunakan oleh pihak pondok pesantren terutama berkaitan dengan manajemen pendidikan dan pelatihan tilawah al-Qur`an, dalam upaya meningkatkan kualitas pendidikan dan pelatihanya. Dan agar hal tersebut dapat dibuktikan dengan peningkatan prestasi peserta didik dalam setiap perlombaan musabaqah tilawatil Qur`an di berbagai tempat.
\end{abstract}


Kata kunci: manajemen pelatihan, manajemen pendidikan, musabaqah tilawatil Qur`an, peserta didik, tilawah Al-Qur`an.

Pertiwi, A. (2018). Manajemen Pendidikan dan Pelatihan Tilawah Al-Qur'an Bagi Calon Peserta Didik Musabaqoh Tilawatil Qur`an. Tadbir Muwahhid, 2(1), 25-32.

\section{PENDAHULUAN}

Al-Qur'an ialah kitab suci umat Islam, dimana pada alam akhirat akan menjadi petunjuk dan pedoman bagi umat Islam tersebut, maka dari itu sangat diharuskan bagi setiap umat Islam untuk membaca, mempelajari dan mengamalkanya. AlQur'an juga menjadi suatu pelajaran untuk kehidupan manusia apabila selalu dibaca, selalu mengamalkanya dan menerapkanya dalam kehidupan sehari-hari. (Al-Hafizh 2011) (Qomar 2015)

Pengajaran membaca al-Qur`an serta dengan murattal dengan keindahan seninya. (Qomar 2015). Maka putra-putri daerah ini memang mempunyai prestasi yang luar biasa, ada dari beberapa peserta didik yang berhasil menjuarai perlombaan tersebut. Sedabgkan yang belum berhasil , dikarenakan sistem dipondok ini memang tidak sepenuhnya selalu diperhatikan, karena pelatihan peseta didik untuk belajar al-Qur`an hanya pada malam hari yaitu sesudah sholat maghrib berjama'ah, dan pada subuh harinya peserta didik belajar tajwid al-Qur’an, dan pada siang harinya bebas aktifitas masing-masing. Karena pondok ini tidak menyediakan lembaga madrasah/sekolah, hanya untuk mempelajari tilawah al-Qur`an saja.

Untuk mengetahui lebih dalam lagi tentang pondok pesantren al-Qur’an ini. Pasti bertanya-tanya tentang mengapa pondok pesantren ini bisa menghasilkan qori-qoriah yang sangat berprestasi, tentu tidak jauh dari cara mengelola atau usaha yang dilaksanakan oleh para Ustadz di pesantren al-Qur`an ini, beliau mengajarkan kepada peserta didik dengan metode secara langsung atau dengan tatap muka, satu persatu santri dipanggil kedepan untuk dites tilawatil al-Qur`an-nya dengan tujuh maqam lagu dan seterusnya setiap malam. Berdasarkan kajian dari latar belakang diatas, maka penulis tertarik untuk meneliti karya ilmiah yang berbentuk skripsi dengan judul: (Manullang 2009) "Manajemen Pendidikan dan Pelatihan Tilawah al-Qur`an Bagi Calon Peserta didik Musabaqoh Tilawatil Qur’an studi kasus di Pondok Pesantren al-Qur`an M. Thoha Al-fasyni Bogor"

Istilah Manajemen terjemahannya dalam bahasa Indonesia sampai sekarang belum ada keragaman. Bila dilihat literatur manajemen, maka akan ditemukan bahwa istilah manajemen mengandung tiga pengertian yang pertama, manajemen suatu proses, kedua, manajemen sebagai kolektivitas orang-orang yang melakukan aktivitas manajemen dan ketiga, manajemen salah satu seni dan suatu ilmu. (Manullang 2009) (Effendy 1986)

Manajemen merupakan ilmu, banyak sekali definisi yang telah dijelaskan oleh para sarjana mengenai manajemen. Kata manajemen berasal dari bahasa Inggris dari kata kerja to manage yang sinonimnya antara lain to hand berarti 'mengurus', to control 'memeriksa' to guide 'memimpin'. Jadi, apabila dilihat dari kata manajemen berarti pengurusan, pengendalian, memimpin, atau membimbing. (Effendy 1986) 


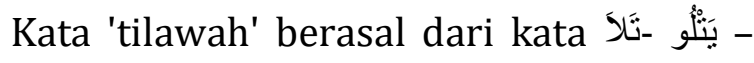
تِلاَوَةً yang berarti membaca atau bacaan, dan tilawah al-Qur`an artinya bacaan al-Qur`an, penjelasan tilawah secara istilah adalah membaca Al Qur'an dengan bacaan yang menampakkan huruf-hurufnya dan berhatihati dalam melafadzkannya agar lebih mudah untuk memahani makna-makna yang terkandung di dalamnya. Tilawah juga merupakan suatu seni suara. (Al-Hafizh 2011). Tartil al-Qur`an adalah membacanya dengan perlahan sambil memperjelas hurufhuruf berhenti dan memulai (Ibtida'), sehingga pembaca dan pendengarnya dapat memahami dan menghayati kandungan pesan-pesannya. (Ropikoh 2014). Berkaitan dengan itu Allah SWT berfirman dalam alQur`an surah ar-rum ayat 30 yang artinya:

"(setelah jelas kesesatan syirik itu) maka hadapkanlah dirimu (engkau dan pengikutpengikutmu, Wahai Muhammad) ke arah Agama Yang jauh dari kesesatan; (turutlah terus) ugama Allah, Iaitu ugama Yang Allah menciptakan manusia (dengan keadaan bersedia dari semulajadinya) untuk menerimanya; tidaklah patut ada sebarang perubahan pada ciptaan Allah itu; itulah ugama Yang betul lurus, tetapi kebanyakan manusia tidak mengetahui.

Musabaqah tilawatil al-Qur`an adalah salah satu jenis kegiatan membaca alQur`an dengan bacaan Mujawwad, yaitu bacaan al-Qur`an yang mengartikan nilai ilmu membaca, seni membaca dan adab membaca menurut pedoman yang telah ditentukan. (Huffazh t.thn.) Sepertinya sudah sering terdengar dengan kata Musabaqah Tilawatil Qur`an (MTQ)

Berdasarkan teori dan fakta maka dapat disimpulkan apermasalahan yang menjadi fokus dalam penelitian ini, adalah bagaimana Manajemen Pendidikan dan Pelatihan Tilawah al-Qur`an bagi calon peserta didik Musabaqoh Tilawatil Qur`an (studi kasus di Pondok Pesantren al-Qur`an M. Thoha Al-fasyni Bogor).

\section{MATERI DAN METODE}

\section{Jenis Penelitian}

Penelitian ini menggunakan metode penelitian kualitatif deskriptif, di mana waktu pengumpulan data, pada umumnya seorang peneliti dapat menemukan data penelitian dalam bentuk kata-kata, gambar, yang dimaksud data disini adalah transkiptranskip wawancara, catatan data lapangan, dokumen pribadi, foto-foto, nota dan lainlainya (Iskandar 2013). Tujuan deskripsi ini adalah untuk membantu pembaca mengetahui apa yang terjadi di lingkungan di bawah pengamatan, seperti apa pandangan partisipan yang berada di latar penelitian, dan seperti apa peristiwa atau aktivitas yang terjadi di latar penelitian (Emzir 2012).

\section{Tujuan Penelitian}

Penelitian ini bertujuan sebagai berikut.

1. Untuk menjelaskan bagaimana strategi manajemen pendidikan tilawah alQur`an bagi peserta didik di pondok pesantren M. Thoha al-fasyni.

2. Untuk mengungkapkan apa saja hambatan, kelemahan, kekuatan, peluang, dalam manajemen pendidikan tilawah al-Qur'an bagi peserta didik di pondok pesantren al-Qur`an M. Thoha al-fasyni.

3. Untuk menyusun perkembangan yang lebih efektif dan efisien dalam manajemen pendidikan tilawah alQur`an di pondok pesantren al-Qur`an M. Thoha al-fasyni. 


\section{Data dan Sumber Data}

Data yang diperoleh dalam melakukan penelitian bersumber dari. Data primer. Untuk memperoleh data-data tersebut digunakan metode pengumpulan data dengan wawancara yang berhubungan dengan manajemen pendidikan dan peatihan tilawah al-Qur'an bagi calon peserta didik msabaqah tilawatil Qur`an. Data primer merupakan sumber utama dalam penelitian ini, dimana datanya adalah gambaran umum tentang manajemen lembaga pendidikan tilawah al-Qur`an serta hasil pengamatan langsung dengan kegiatan bagi calon peserta didik musabaqah tilawatil Qur`an.

\section{Teknik dan Prosedur Pengumpulan Data}

Dalam penelitian ini metode pengumpulan data yang digunakan meliputi:

1. Observasi Partisipatif yaitu salah satu cara pengumpulan data yang utama dalam mengkaji situasi sosial yang dijadikan sebagai objek penelitian ini dengan menggunakan teknik observasi partisipatif.

2. Wawancara mendalam yaitu untuk memperoleh data yang memadai sebagai cross ceks, peneliti juga menggunakan teknik wawancara mendalam dengan subjek yang terlibat dalam interaksi sosial yang dianggap memiliki pengetahuan.

3. Dokumentasi yaitu mengambil data-data yang berkaitan dengan penelitian dari sumber-sumber referensi seperti dari buku-buku, majalah, internet, atau dokumen yang berisi gambaran umum seperti data tentang struktur manajemen pendidikan tilawah alQur’an, visi dan misi didirikan pondok pesantren al-Qur'an M. Thoha Al-fasyni Bogor.

\section{Prosedur Analisis Data}

Analisis data adalah proses mencari dan menyusun secara teratur data yang diperoleh dari hasil wawancara, catatan lapangan, dan dokumentasi. Dalam mendapatkan hasil dari data-data yang diperoleh dalam penelitian, maka diperlukan adanya teknik analisis data (Sugiyono 2009). Dalam penelitian ini penulis menggunakan teknik analisis data yang dikenal dengan Content Analisis atau analisis isi. Untuk mempermudah dalam menganalisis content (isi) dalam penelitian ini maka penting untuk menggunakan pendekatan-pendekatan metode yang lain, di antaranya sebagai berikut.

1. Induksi

Metode induktif adalah cara berpikir yang berpijak dari fakta-fakta yang bersifat khusus, kemudian diteliti dan akhirnya ditemui pemecahan persoalan yang bersifat umum.

2. Reduksi data

Metode deduktif yaitu menyaring data yang diperoleh dilapangan yang masih ditulis dalam bentuk uraian atau laporan terperinci, laporan tersebut direduksi, dirangkum, dipilih, difokuskan, pada bantuan program, disusun lebih teratur sehingga mudah dipahami (Sugiyono 2009).

\section{Pemeriksaan Keabsahan Data}

Jadi keabsahan data bertujuan untuk membuktikan bahwa apa yang sudah diamati oleh peneliti sesuai dengan apa yang sesungguhnya di lapangan. Untuk memperoleh keabsahan data tersebut, peneliti menggunakan triangulasi. Triangulasi dalam hal ini diartikan sebagai 
pengecekan data dari berbagai sumber dengan berbagai cara, dan berbagai waktu. Dengan demikian terdapat triangulasi sumber, trangulasi teknik pengumpulan data dan waktu.

\section{HASIL DAN PEMBAHASAN}

\section{Sistem Seleksi Peserta Didik di Pondok Pesantren}

Syarat dan ketentuan masuk pondok pesantren al-Qur`an M. Thoha Al-fasyni bagi yang biaya pribadi tidak diterapkan syarat tertentu hanya saja peserta didik harus sudah mempunyai dasar bisa membaca ayat suci al-Qur`an dengan lancar dan menguasai ilmu tajwid, karena dipondok ini bebas untuk belajar dan mengikuti pembelajaran tilawah al-Qur`an. Karena disini memang merupakan tempat untuk mengembangkan bakat atau potensi yang dimiliki peserta didik biar menjadi lebih berkualitas dan bisa mengikuti lomba-lomba musabaqah tilawatil Qur`an pada setiap tahunya. Bagi yang mendapatkan beasiswa yaitu bebas biaya tempat tinggal, makan, dan uang saku, harus memiliki potensi dan bakat yang lebih, karena yang mendapatkan beasiswa tersebut akan mewakili daerah kabupaten masing-masing untuk menjadi yang terbaik didaerahnya. Syaratnya harus bisa menguasai lagu tilawah al-Qur`an, mampu menjuarai setiap lomba (wawancara personal dengan Nasution, 2016).

\section{Materi Pelatihan atau Pembelajaran Pondok Pesantren}

Dalam sistem pembelajaran pendidikan tilawah al-Qur'an di pondok pesantren alQur`an M. Thoha Al-fasyni yaitu menggunakan sistem pembelajaran membeo dengan berbagai metode di antaranya sebagai berikut. a. Mengikuti Dalam pelatihan seni baca alQur`an semua peserta didik mengikuti bacaan yang dicontohkan oleh ustadz dan di ikuti oleh peserta didik.

b. Mempolakan dengan satu maqro' yang diberikan.

c. Mengembangkan Setelah peserta didik menguasai dengan satu maqro' dengan pola variasi yang diberikan, setelah itu para peserta didik di beri tugas untuk memindahkan pola variasi lagu tersebut ke surah dan ayat yang berbeda.

Dari ketiga wacana tersebutlah metode yang diterapkan oleh pendidik sekaligus pemimpin pondok al-Qur`an M. Thoha ALfasyni dalam mengajarkan seni-seni lagu alQur’an yang disebut dengan lagu-lagu tilawah al-Qur’an, dan dari sini juga banyak mengahasilkan para qori dan qoriah sampai jenjang internasional (wawancara personal dengan Alhifni, 2016).

\section{Metode Pembelajaran Tilawah al- Qur`an}

Metode yang digunakan bisa dikenal dengan metode terpola. Dinamakan dengan metode terpola karena sesuai dengan makna secara harfiahnya yaitu pertemuan. Oleh karenanya dalam pelaksanaanya dilakukan dengan cara bertatap muka antara ustadz pimpinan dengan para santriwan dan santriwati. Dinamakan terpola karena pembelajaran yang dilakukan untuk mengahasilkan pola tilawah yang yang telah dipolakan terlebih dahulu oleh ustadz sehingga dalam lima sampai tujuh kali pertemuan mampu menghasilkan satu pola lagu tilawah al-Qur`an (wawancara personal dengan Alhifni, 2016)

\section{Kegiatan Pendidikan dan Pelatihan Tilawah al-Qur`an}

Di dalam pondok pesantren al-Qur'an $\mathrm{M}$. Thoha Al-fasyni ini rata-rata peserta didik 
sudah mempunyai dasar untuk mempelajari lagu-lagu tilawah, karena yang masuk kedalam pesantren al-Qur`an M. Thoha Alfasyni ini rata-rata orang orang yang terpilih yang juga telah berkesinambung di dunia musabaqah tilawatil Qur`an, sehingga ratarata santriwan dan santriwatinya yang di pesantren al-Qur`an M. Thoha Al-fasyni ini mampu meraih prestasi di dalam perlombaan musabaqah tilawatil Qur`an (MTQ), mulai dari tingkat Kecamatan, Kabupaten, Provinsi, Nasional, bahkan Internasional (wawancara personal dengan Nasution, 2016).

\section{Pelaksanaan dan Kegiatan Penerapan Variasi Lagu-lagu pada Pendidikan Tilawah al-Qur`an}

Tahapan pembelajaranya berdasar pada pendapat Alhifni (wawancara personal dengan Alhifni, 2016) adalah seperti sebagai berikut.

1. Diawali pertemuan peserta didik bersama-sama dengan al-mukarrom, membaca ummul Qur`an (surah Alfatihah). Kemudian dilanjutkan dengan membaca do'a sebelum pengajian dimulai, dengan maksud biar pembelajaran yang dilaksanakan mendapat keridhoan, keberkahan serta kemudahan dari Allah SWT.

2. Ustadz memerintahkan salah satu peserta didik untuk menjadi contoh dalam pembelajaran, jadi seorang peserta didik tersebut diperintahkan maju kedepan, metode mengikuti seperti inilah yang dilaksanakan pada proses pembelajaran tilawah al-Qur’an di pondok pesantren al-Qur`an M. Thoha Al-fasyni.

3. Jika lagu-lagu yang diberikan belum didapat oleh peserta didik yang di perintahkan kedepan serta para peserta didik, maka ustadz akan mengulang- ulangi lagu tersebut, sehingga dapat mudah bagi pembaca untuk mengikuti.

\section{Mengkoordinasi Pengembangan Pendidikan Tilawah Al-Qur’an}

Setelah semua peserta didik menguasai dengan lagu-lagu yang telah dipolakan, maka usatdz memerintahkan kepada seluruh peserta didik untuk mengembangkan lagu-lagu yang telah dipolakan sebelumnya kesurah dan ayat yang belum pernah dipelajari. Setelah peserta didik menguasai dan bisa mengembangkan maupun memindakan peserta didik untuk membacakan ayat yang telah mereka kembangkan ke ayat yang telah mereka pelajari (wawancara personal dengan Nasution, 2016).

\section{Jadwal Kegiatan Pembelajaran Pondok Pesantren}

Pembelajaran tilawatil Qur`an pada pesantren al-Qur`an M. Thoha Al-fasyni merupakan kegiatan rutin yang dilaksanakan setiap sesudah shalat maghrib yaitu dilaksanakan pada pukul 18:00-21:00 WIB, karena peasantren ini di dirikan benar-benar bertujuan untuk membangun generasi yang menguasai dibidang tilawah al-Qur`an, memang khusus untuk mempelajari seni baca al-Qur`an atau disebut juga dengan tilawah al-Qur`an selain itu selingi dengan adanya yang menghafal al-Qur`an hanya saja tidak terlalu memfokuskan. Itulah sistem pembelajaran dan kegiatan peserta didik di pondok pesantren al-Qur`an M. Thoha Al-fasyni yang rutin dilaksanakan pada setiap ba'da maghrib kecuali malam minggu dibebaskan pembelajaran (wawancara personal dengan Alhifni, 2016). 


\section{Teknik Latihan dan Pemeliharaan Suara dan Nafas pada Tilawah al- Qur’an}

Tilawah al-Qur`an salah satu bidang kesenian yang menjadi bagian dari tilawah al-Qur’an, yaitu sebuah aktivitas yang dilaksanakan oleh qori-qori'ah, merupakan bacaan ayat-ayat al-Qur'an dengan bertajwid, bernada, berirama, bervariasi. Oleh karena itu sudah menjadi kewajiban bagi orang yang berseni dalam membaca alQur`an untuk memiliki suara dan pernafasan yang baik, karena dengan suara dan pernafasan yang baik, karena dengan suara dan pernafasan yang baik tentunya akan menambahkan keindahan dalam membaca ayat-ayat al-Qur`an. Bacaanyapun akan selalu terngiang dan dirindukan oleh orang-orang yag mendengarnya. Dan boleh dibilang sudah kewajiban bagi setiap orang yang sudah memahami al-Qur`an harus mengamalkan isi kandunganya dalam kehidupan sehari-hari.

\section{KESIMPULAN DAN IMPLIKASI}

\section{Kesimpulan}

Adapun kesimpulan dalam penelitian ini yaitu sebagai berikut.

1. Dari segi Profesionalnya kegiatan hasil pengamatan dalam penelitian yang berjudul manajemen pendidikan tilawah al-Qur`an bagi calon peserta didik musabaqah tilawatil Qur`an juga menemukan adanya cara memimpin suatu pembelajaran pendidikan tilawah tersebut dengan mudah dan sudah terpola. Diantaranya memimpin sistem pembelajaran dengan cara metode membeo yaitu peserta didik mengikuti guru, mempolakan variasi-variasi lagu tilawah al-Qur`an, dan mengembangkanya dengan terus melatih dan mengevaluasi yang telah diajarkan. Latihan pernafasan juga harus rutin dilakukan karena itu adalah modal kita untuk mendapatkan prestasi yang baik, seperti lari pagi, renang sambil menahan nafas dalam air, bulu tangkis, latihan rutin dengan membacakan surah al-fatihah dalam satu nafas tidak boleh berhenti, serta tidak membiasaka tidur pagi dan tiur terlalu malam.

2. Dari segi berkualitasnya yaitu hasil penelitian menunjukkan adanya metode baru dalam manajemen pendidikan tilawah al-Qur'an yang diterapkan dipondok pesantren al-Qur`an M. Thoha Al-fasyni, yaitu metode membeo terpola. Dimana metode ini dilaksanakan dengan adanya tatap muka antara pengajar dan peserta didik yaitu antara ustadz dan peserta didik. karena dengan metode inilah terbukti mampu menghasilkan qori-qori'ah terbaik yang penuh prestasi, yang bisa diandalkan baik dari tingkat kecamatan, kabupaten, provinsi, nasional, maupun internasional.

\section{Implikasi}

1. Manajemen pendidikan tilawah alQur`an ini maka pembelajaran yang cukup sulit untuk diikuti, butuh beberapa lama untuk bisa menyesuaikan dan bisa mempraktikan, selain itu juga harus terus berusaha berlatih dan berdo'a, akan tetapi dengan cara atau metode yang telah diterapkan dengan sedemikian rupa, maka diharapkan bagi siapa saja ingin mendalami dan mempelajari ilmu seni baca al-Qur`an jangan mudah menyerah jangan pernah bosan terus berlatih dan berusaha.

2. Bagi lembaga yang diteliti, manajemen pendidikan dan pelatihan tilawah alQur’an adalah salah satu muatan kurikulum yang diamati oleh para 
peserta didik. Agar tercipta pembelajaran yang efektif dan efisien,

3. Bagi Peserta didik, harus terus mengikuti program pesantren dengan penuh kesadaran tanpa ada rasa keterpaksaan, terutama dalam hal pembelajaran tilawah al-Qur'an bahwa kelembagaan juga ingin peserta didiknya dapat berhasil dan berkembang dengan prestasi yang telah dikembangkan.

4. Demikianlah saran-saran dari penulis, semoga hasil penelitian ini bisa memberikan masukan yang baik dan positif dalam manajamen pendidikan tilawah al-Qur`an.

\section{DAFTAR PUSTAKA}

Emzir. (2012). Metodologi Penelitian Kuantitatif Dan Kualitatif. Jakarta: Rajagrafindo persada.

Iskandar. (2013). Metodologi Penelitian Pendidikan dan Sosial. Jakarta: Ciputat Mega Mall.

Manullang. (2009). Dasar-dasar Manajemen. Yogyakarta: Gadjah Mada University Press.

Mujamil, Q. (2015). Dimensi Manajemen Pendidikan Islam. Malang: Penerbit Erlangga.

Ropikoh. (2014). Metode Pembelajaran Tilawatil Qur`An dalam Menghasilkan Qori Internasional. Skripsi: Bogor.

Sugiyono. (2009). Metode Penelitian Kuantitatif Kualitatif dan R\&D. Alfabeta: Bandung. 